UDK: 811.111 .42

DOI: $10.22363 / 2312-9182-2016-20-4-43-55$

\title{
DISCOURSE ANALYSIS AND PRAGMATICS: THEIR SCOPE AND RELATION
}

\author{
Laura Alba-Juez \\ UNED \\ Passeo Senda del Rey, 7 \\ Ciudad Universitaria, 28040 Madrid, Spain
}

\begin{abstract}
In this article I delve into the seas of the disciplines of Discourse Analysis and Pragmatics, trying to perform the difficult task of delimiting their scope and discussing their common and non-common ground, in order to present a general idea of the state of the art of both disciplines in the $21^{\text {st }}$ century. Being conscious of the fact that one can learn a great deal about any field by observing what its practitioners do, and precisely because these disciplines are hard to delimit, I also discuss what it is that pragmaticians and discourse analysts actually do. The concepts of text and discourse are explored by looking into different approaches and studies in the areas of Text Linguistics and Discourse Analysis, as well as into how they have evolved from their beginnings to the present time. The main schools of Pragmatics, the Anglo-American and the European Continental (Huang 2016) are also explored, in order to compare their viewpoints and their relationship with the field of discourse analysis. As I see it, Pragmatics is not the same as, but is an indispensable source for, discourse analysis: it would be impossible to analyze any discourse without having a solid basic knowledge of pragmatic phenomena and the ways in which they work and interact (Alba-Juez, 2009: 46). I also examine some concepts and issues that are crucial for the topic of this paper, such as the concepts of context, cognition or culture, and the need to develop pragmatic awareness.
\end{abstract}

Key words: pragmatics, discourse, discourse analysis, context, cognition, culture

\section{INTRODUCTION}

Delimiting a field of study or knowledge is never a simple task, and the case for Discourse Analysis and Pragmatics is no exception, considering that they are both subdisciplines of Linguistics that share common ground with each other and with Text Linguistics as well, the three of them having fuzzy boundaries. As I (and other authors such as Schiffrin 1994) see it, Pragmatics is not the same as Discourse Analysis, but is an indispensable source for any discourse analytic study: it would be impossible to analyze any text or discourse without having a solid knowledge of pragmatic principles and phenomena. In the following sections I will try to describe the scope of action of these disciplines, pointing to their similarities and differences by looking into what their respective practitioners do, as well as their evolution and the kind of studies being covered by each one of them. First, I will discuss the scope of Text Linguistics in comparison with Discourse Analysis (or Discourse Studies), and then I will pass on to examine what I understand to be the common ground and differences between Discourse Analysis and Pragmatics. 


\section{TEXT LINGUISTICS AND DISCOURSE ANALYSIS}

Part of the fuzziness described above comes from the fact that, as I have stated in a previous publication (Alba-Juez 2009: 6), the terms text and discourse are used in a variety of ways by different researchers. Furthermore, there is a considerable number of theoretical approaches to both Text Linguistics and Discourse Analysis which in many cases belong to very different research traditions, even when they share similar basic tenets.

In everyday popular use the term text is normally restricted to written language and the term discourse is restricted to spoken language. However, modern Linguistics has introduced a concept of text and/or discourse that includes every type of utterance; written or spoken. Thus both text and discourse may refer to a political speech, a whatsapp message, a magazine article, an oral interview, a conversation, or a cooking recipe, just to give a few examples. The terms text and discourse, therefore, are sometimes used by linguists to mean the same and because of this one might conclude that Text Linguistics and Discourse Analysis are the same too, but in general, the tendency in Text Linguistics has been to present a more formal and experimental approach, while that of Discourse Studies can be said to be oriented towards a functional approach.

Formalists are apt to see language as a mental phenomenon, while functionalists see it as a predominantly social one. But this distinction cannot be said to be so clearcut: many authors, like Schiffrin (1994), integrate both the formal and the functional approaches in their analysis of texts, and under this light Discourse Analysis can be seen as all-embracing term including Text Linguistics and other approaches such as Critical Discourse Analysis, Conversation Analysis or Discursive Psychology, just to name a few.

The main concern of text linguists is the structure of text; in general they do not pay so much attention to context as discourse analysts do. Some authors, such as Halliday, believe that text is everything that is meaningful in a particular situation: "By text, then, we understand a continuous process of semantic choice" (1978: 137). Schiffrin (1994: 363) points out that all approaches within Discourse Analysis view text and context as the two kinds of information that contribute to the communicative content of an utterance. In terms of utterances, then, text is the linguistic content, and context refers to the world in which people produce the utterances, which affects the meaning finally set by the interlocutors in their interaction. Discourse Analysis includes utterances, and consequently both text and context, as its object of study. So following this line of thought, and as anticipated above, Text Linguistics can be considered as one school within Discourse Studies whose concern is mainly the textual part of the message, rather than the contextual one. Crystal's (1997) definition of Text Linguistics as "the formal account of the linguistic principles governing the structure of texts" is in sync with this view.

On a different light, the relationship between these two approaches may be seen as an evolution of one into the other: For many authors, what started as Text Linguistics can be said to have evolved into what we nowadays call Discourse Analysis or Discourse 
studies. This is clearly the case of van Dijk, whose work may be said to have undergone a progressive "integration" of both disciplines. In his biographical article of 2002, van Dijk explains how his research evolved from Text Grammar to Critical Discourse Analysis: He started in the 1970s by giving an explicit description of the grammatical structure of texts, but he realized that there were other structures beyond the structure of the sentence (thereby introducing the notion of macrostructure), and that another fundamental notion to analyze the meaning of texts was that of coherence. He then took interest in the study of power and ideology, which eventually placed him within the discourse analytic approach later known as Critical Discourse Analysis. Other important and new concepts were introduced by other text linguists, such as sociocultural knowledge and mental models (Johnson-Laird 1983), which inevitably made text analysts move beyond the text into the different contexts surrounding speech, including other aspects of human interaction having to do with social, psychological or cognitive factors. Thus the text started to be seen as a functional unit, which led into a "discourse processing" stage in which analysts "set about developing process models of the activities of discourse participants in interactive settings and in 'real time"' (de Beaugrande, 1997: 61-62).

De Beaugrande and Dressler (1981) define text as a communicative event that must satisfy seven criteria, the first two of which (cohesion and coherence) may be defined as text-internal, and the remaining five (intentionality, acceptability, informativity, situationality, and intertextuality) as text-external (Tischer et al., 2000). The analytical approaches oriented towards 'pure' Text Linguistics give more importance to textinternal criteria, while the tradition in Discourse Analysis has always been to give as much or even more importance to the external factors, for they are believed to play a role in communication which is as essential as that of the text-internal factors. Thus, in spite of the fact that De Beaugrande and Dressler place their work within Text Linguistics, it can also be placed within, and can be said to have evolved into the realm of Discourse Analysis, considering they take into account aspects of both text and context in their model. In fact, De Beaugrande's (2002) definition of Text Linguistics as "the study of real language in use" does not differ from many of the definitions of Discourse Analysis given by different authors adopting a functional approach to the study of language. Slembrouck is one of these authors, and he defines Discourse Analysis as "mainly the linguistic analysis of naturally occurring connected speech or written discourse" (2006: 1). He adds that it attempts to study the organization of larger linguistic units than the sentence or the clause, such as conversational exchanges or written texts, which therefore involves the concern with language use in social contexts. A few other definitions supporting the functional perspective are the following:

The study of discourse is the study of any aspect of language use (Fasold, 1990: 65).

The analysis of discourse is, necessarily, the analysis of language in use. As such, it cannot be restricted to the description of linguistic forms independent of the purposes or functions which these forms are designed to serve in human affairs (Brown \& Yule, 1983: 1).

Discourse... refers to language in use, as a process which is socially situated (Candlin, 1997: ix). 
...I see discourse analysis as a research method that can be (and is being) used by scholars with a variety of academic and non-academic affiliations, coming from a variety of disciplines, to answer a variety of questions (Johnstone, 2008: xiii).

It is clear that all definitions within a functional perspective refer to language in use, and include the idea that language is socially situated and therefore cannot be properly analyzed if these aspects are not included in the whole picture. Furthermore, an important characteristic of Discourse Studies, which is emphasized in Johnston's definition above, is that they are essentially multidisciplinary, which means that these studies cross the Linguistics border into different and varied domains, such as semiotics, psychology, anthropology, psychology or history. Thus, it is clear that when analyzing discourse, researchers cannot only focus on form or "purely" linguistic facts; they need to pay equal or more attention to language use in relation to social, political and cultural aspects. As Johnstone puts it:

Discourse Analysis [...] is an open-ended heuristic, a research method consisting of a set of topics to consider in connection with any instance of discourse. This heuristic can help insure that discourse analysts are systematically paying attention to every possible element of the potential meaning of a stretch of talk or writing: every kind of context, every resource of creativity, and every source of limitation and constraint on creativity (2008: xiv).

As anticipated above, not all researchers use and believe in the same definition of text and discourse. I will start the conclusion of this section by saying that my own view is simple and very much in sync with the functionalist approach to discourse, considering that, as the above definitions by different authors reveal, Discourse Analysis deals with the study of language in use, and it includes the observation and scrutiny of both text and context as essential parts of utterances and of discourse as a whole. In fact, Discourse Analysis is an outcome of the Functional approach to Linguistics, and would make no sense without it. Even so-called 'formal' approaches within the field have emanated from a functional perspective. As for the distinction between the terms text and discourse, for practical purposes some authors (e.g. Schiffrin 1994, Alba-Juez 2009) adopt a definition of the term text that covers a narrower scope than the term discourse: text refers only to the linguistic part of the message, while discourse refers to both text and context, the latter including not only the linguistic context but other types, such as the social, the cultural or the emotional context (Alba-Juez \& Mackenzie, 2016).

My view is supported by the fact that all discursive approaches - without exception - believe that a good linguistic description should go beyond the sentence and that there are certain meanings and aspects of language that cannot be properly understood if their study is limited to the syntactic analysis of sentences. Hence there is no discourse study that can be said to be devoid of the analysis of at least some aspect of context, and that is not interdisciplinary in some way or another. By way of illustration, I am now going to name and refer to the work done by a few discourse analysts including myself, but any work within the field would be just as representative. Dooley and Levinsohn (2000: iii) state that in their analysis they "follow a functional and cognitive [my italics] approach that seems to be a good approximation of how discourse is actually produced and understood". They therefore analyze numerous texts throughout their 
book, taking into account several aspects and dimensions of their respective discursive situations which go beyond the mere words spoken or written, such as the means, the manner and the medium of production, along with the genre, the people being referenced, or the conversational turns and moves (in case of the analysis of dialogues). Also, in my own research on verbal irony (e.g. Alba-Juez [1996] 2001, Alba-Juez \& Attardo 2014, Alba-Juez 2014) I have not only looked into the 'pure' linguistic content of the numerous ironic utterances I have analyzed, but also - among other things the politeness strategies, the cognitive mechanisms, the humorous undertones, and very specifically, the different discourse functions fulfilled by them in different contexts. A simple morphological or syntactic analysis of the sentences involved would have born no fruit, and would have explained nothing regarding the final ironic meaning intended and understood by the interlocutors involved in every example/situation analyzed.

Thus, the discursive perspective implies looking into language use as necessarily social, and as such, as a phenomenon having common characteristics with other social and cognitive phenomena. Hence an accurate and realistic description of language should account for real facts occurring within actual human interaction. But human communication and cognitive phenomena, as seen from a functional perspective, form part of dynamical systems which so far and paradoxically, are very difficult to describe in accurate terms: there are many multifaceted interrelated variables to be considered, some of which are very difficult to grasp or control, therefore making any prediction only probabilistic. All the more so if we consider that these variables are not only linguistic in nature: When performing discourse analysis researchers may, for instance, engage themselves in Functional Grammar, Sociology, Pragmatics, Psychology and Cognitivism at the same time, hence having to deal with multiple and multifarious variables which interact with one another.

Consequently and to conclude, the current aim in DA is to describe language where it was originally found, i.e. in the context of human interaction, and this interaction often involves other media besides language. Examples of these other semiotic systems may be gesture, dance, song, photography, cyberspace or clothing, and this is why nowadays many discourse analysts are trying to explain the connection between these systems and language. In order to achieve these aims, different researchers have taken different approaches, and this is one of the reasons why current research in Discourse Analysis flows from different academic fields.

\section{APPROACHES TO DISCOURSE STUDIES}

Z. Harris $(1951,1952)$, the first linguist to use the term discourse analysis, was a formalist: he viewed discourse as the next level in a hierarchy of morphemes, clauses and sentences. This view was later criticized due to the results shown by functional researchers like Chafe $(1980,1987,1992)$, who argued that the units used by people in their speech have a semantic and an intonational closure, but not necessarily a syntactic one, and therefore cannot always be categorized as sentences. Indeed, functionalists focus on the purposes of language, to such an extent that some of them defend the notion that language and society cannot be thought of as independent (Fairclough 1989, Fou- 
cault 1980). Thus they do not see discourse as a level in a hierarchy, but as an all-embracing concept including not only the propositional content, but also the social, cultural or cognitive contents.

As I and many other authors (e.g. Schiffrin 1994) see it, both the formal and functional paradigms should be integrated in discourse studies. Discourse deals with utterances, and utterances can be defined as "units of linguistic production (whether spoken or written) which are inherently contextualized" (Schiffrin, 1994: 41). It follows, then, that the nature of discourse studies is not only sequential or syntactic, but also and more importantly, semantic and pragmatic. Thus within discourse analysis one should consider, together with the 'purely' linguistic content, other interaction forms such as sign language, dramatization or so-called bodily hexis (Bourdieu, 1990), which inevitably takes us to the conclusion that discourse is multi-modal, for it uses more than one semiotic system and performs several functions at the same time.

Wetherell et al. (2001) summarize all that has been expounded so far when they write about four approaches to DA, namely, 1) The model that views language as a system and therefore its researchers aim to find patterns; 2) the model that is based on the activity of language use, and therefore language is viewed as a process and not as a product; thus its researchers focus on interaction; 3 ) the model that searches for language patterns associated with a given topic or activity (e.g. legal discourse, psychotherapeutic discourse, etc.); 4) the model that looks for patterns within broader contexts, such as "society" or "culture". Within this last model language is viewed as part of major processes and activities, and as such the interest goes beyond language (e.g. the study of sexism or racism in discourse interaction).

It should be noted, however, that the above models present very general approaches; in fact, it can be said that each discourse analyst proposes new forms of analysis that broaden previous views on the topic, and that therefore there are as many approaches to discourse as there are researchers devoted to the field. It is nevertheless also fair to acknowledge that all strands of research within the field share a common ground, and that in some cases it is difficult to distinguish among them. Some of the best-known schools are Interactional Sociolinguistics, Conversation Analysis, Variation Analysis, Narrative Analysis, Critical Discourse Analysis, or Mediated Discourse Analysis. In spite of the differences in approach, all of these schools share the common characteristic that they do not focus on language as an abstract system. Instead, they are interested in what really happens when people engage in linguistic interaction, in how they do things with language, i.e. in how they express their feelings, exchange ideas or entertain other people, among infinite other possibilities.

\subsection{So what do discourse analysts do?}

In order to learn about a given discipline, it is useful to look at what practitioners do. Discourse analysts may explore the language of science, face-to-face conversations, telephone conversations, whatsapp messages, social network discourse, etc., and when doing so they may look into power relations, the structure of turn-taking, politeness strategies, the linguistic manifestation of racism or sexism, the structure of narrative, the use of persuasive language and numerous other aspects of language in use. They are 
interested in the actual patterns of use in naturally-occurring texts. Once transcribed and annotated, these texts are known as the corpus, which constitutes the basis for analysis. Thus, discourse analysts necessarily take a corpus-based approach to their research (Alba-Juez 2009: 18).

Discourse analysts have helped (and are helping) to shed light on both the production and the interpretation phases of discourse, i.e. how speakers/writers organize their discourse in order to indicate their intentions, and how hearers/readers interpret what they hear, read or see. They have also contributed to answer important research questions which have led, for instance, to the identification of the evaluative systems of language (e.g.: Martin \& White 2005, Hunston and Thompson 2000, Thompson and Alba-Juez 2014), the mechanisms for expressing emotion through language (e.g.; Foolen 2012, 2016; Dewaele 2013), or the cognitive abilities involved in the use of symbols or semiotic systems (e.g.: Forceville \& Clark 2014), just to name a few of these important contributions.

\section{BUT HOW DOES PRAGMATICS GET INTO THE PICTURE?}

Some of the definitions of Pragmatics are almost identical to some of the definitions of Discourse Analysis, which may lead us to think that both fields of study are the same. Such definitions of Pragmatics can be placed within the broader approach called Macro-Pragmatics, and they differ from those given by the narrower approach known as Micro-Pragmatics. My view of Pragmatics is more in agreement with the latter approach, and therefore I do not see it as identical with Discourse Analysis. Pragmatics is, however, an indispensable source for Discourse Analysis which shares some common ground with it but differs in method and scope. Indeed, both disciplines share the view that it is not desirable to deal with abstract idealizations of how language is structured, or prescriptive rules about how language should work, and hence what is desirable is to deal with how, when, why, etc. speakers/writers actually use language for different purposes. However, as was pointed out in 3, while Discourse Analysis is basically a general term for a number of techniques and approaches (such as Conversation Analysis, Critical Discourse Analysis, etc.) to analyze written, spoken or sign language, Pragmatics does not necessarily include those approaches within its scope. A researcher performing an analysis of discourse and engaged in any of these approaches will necessarily be using pragmatic concepts and knowledge, but a researcher doing pragmatic analysis will not necessarily form part of any discourse-analytic school of thought.

\subsection{The scope of Pragmatics: Central topics and main approaches}

Pragmatics basically deals with meaning, but meaning within this discipline is of a much broader scope than in traditional, truth-conditional Semantics. A crucial distinction is here made between the basic meaning of an expression resulting from its syntactic structure (i.e. semantic meaning), and what someone means by using such an expression in a given context (i.e. pragmatic meaning). Thus pragmatic research and work, like discourse analytical work, is inevitably linked to a functional perspective on language, but at the same time it usually takes into account many formal aspects that contribute to the determination of the meaning of any utterance. 
One of the central concerns of Pragmatics is to understand the mechanisms that allow speakers to work out the hidden, indirect or implied meanings of utterances or whole texts. Hence the vast amount of studies on topics such as inference, implicatures or phenomena like verbal irony or metaphor found within the field. Another important concern is to understand the linguistic mechanisms of reference and deixis, two phenomena that depend very much on contextual factors. As we know, and just to give an example, the pronouns $I$, you or they may refer to different people depending on the interactants, the situation and the context of talk. Pragmatics, then, has a lot to say about the underdeterminacy of language, and it looks into the nature and inherent characteristics of the many and various mechanisms (such as reference, deixis, conventional and conversational implicatures, or presuppositions) that human beings set into motion in order to encode and decode underdetermined utterances.

As far as the approach to pragmatics is concerned, it can be said that the views of pragmaticians all over the world are divided into two main schools: a) the Anglo-American school, and b) the European Continental school. The Anglo-American school views Pragmatics as one more of the core components of a linguistic theory, along with phonetics, phonology, morphology, syntax and semantics. Authors such as Levinson (1983), Leech (1983), Yule (1996) or Cummings (2005) support this view, whose central topics of inquiry include implicature, presupposition, speech acts, deixis and reference. (Huang 2016). The European Continental school of Pragmatics advocates a broader perspective, and is supported by linguists such as Jef Verschueren, who defines Pragmatics as "the cognitive, social, and cultural science of language and communication" (2009: 1). Bublitz and Norrick (2011: 4) point out that within this broader point of view Pragmatics is seen as "the scientific study of all aspects of linguistic behaviour", and as an area of research that is "fundamentally concerned with communicative action in any kind of context". From the Continental perspective, therefore, "Pragmatics is not confined within the boundaries of just one linguistic component, but is 'omnipresent' in all components and every aspect of linguistic behaviour" (Alba-Juez \& Mackenzie, 2016: 13). Furthermore, the tendency of this extensive view has been to consider pragmalinguistic data as phenomena that necessarily have to be studied in relation to other domains, which has given rise to new sub-areas of research such as computational, historical, anthropological or experimental Pragmatics.

In spite of the above, and as Huang (2015) points out, a reconciliation of the component and the perspective views can be observed in the work of some pragmaticians (e.g. Mey [1993] 2008, Ariel 2010), joining the knowledge and strengths of both perspectives. Mey refers to this convergence of view in the following way:

Thus, we could have a pragmatic component, understood as the set of whatever pragmatic functions can be assigned to language, along with a pragmatic perspective, i.e., the way these functions operate. We could either ask how users 'mean what they say', that is, how they communicate, using language, or how they 'say what they mean', employing the linguistic devices at their disposal to express themselves ([1993] 2008: 9).

The Anglo-American school could therefore be identified with what has been called micro-pragmatics, whereas the Continental European School, with so-called macro- 
pragmatics. Micro-pragmatics is mainly concerned with specific theoretical discussions about topics such as implicature, reference or deixis, while macro-pragmatics places the emphasis more on the perspective taken than on any theoretical point in particular, "which would simply entail taking a functional perspective (in a very broad sense) on the study of language in all its aspects" (Alba-Juez \& Mackenzie, 2016: 14).

As the reader may have noticed by now, the European Continental definition of Pragmatics does not seem to differ in essence from the definition of Discourse Analysis advocated by the functional view referred to in 2 and 3 above. Both claim that the analysis of language in use and in context constitutes their scope of research, which makes it inevitable for us to ask the following question: If Pragmatics is about 'the study of communicative action in all contexts', how does it differ from Discourse Analysis, and why would it be necessary in the first place? I will respond by reproducing the view already expressed in that respect in Alba-Juez \& Mackenzie (2016), for it summarizes what I consider to be the fundamental distinction between these two disciplines, and the point I want to make to conclude this section:

"It is very likely that, if we define Pragmatics as a discipline that 'studies language in all its aspects', we shall immediately start to wonder if there is any use in distinguishing it from Discourse Analysis or even Linguistics (if taken in a broader sense). Thus, while a convergence of both approaches seems desirable, the all-embracing character of macro-pragmatics seems too broad to make Pragmatics a necessary sub-field of Linguistics, distinct from any other.

Along this line of thought, then, we feel more prone to think that both the findings and objectives of micro and macro-pragmatics are of great use for linguists and discourse analysts, but that, whereas pragmatics is an indispensable source for the analysis of discourse (Alba-Juez, 2009: 46), it is, however, not the same thing. Pragmatics provides discourse analysts with important tools and basic concepts without which their work would be impossible to carry out, but discourse analysis is a broader, more empirically-oriented discipline that is not particularly interested in theorizing about, for instance, inferences or deixis (Pragmatics already does that!). Among other things, Discourse Analysis includes many schools and traditions (e.g. Critical Discourse Analysis, Ethnography of Communication, etc.) which in our view do not form part of Pragmatics, although they do draw on its findings." (2016: 15).

\section{SUMMARY AND CONCLUSIONS}

In this article I have mainly tried to elucidate the scope and interests of two very important sub-disciplines of Linguistics: Discourse Analysis and Pragmatics. In addition, when discussing the scope of Discourse Analysis, some remarks have been made regarding both its common and non-shared ground with Text Linguistics. The main points I have made are the following:

- There are two main approaches to Discourse Analysis: the formal and the functional. Formalists focus more on the text-internal characteristics of language, while functionalists concentrate on the analysis of language in use, giving as much as, or even more importance to the context than to the text of utterances. 
- Text Linguistics is a kind of discourse analysis that tends more towards a formalist perspective, for it focuses on the structure of the text and the text alone, rather than on the external aspects of context. The rise of Discourse Analysis in the second half of the $20^{\text {th }}$ century brought about a consideration not only for text but also for context, therefore giving the text-external factors an importance that had not been given to them by grammarians or text linguists before. And this was how for many authors (such as van Dijk), what started as text linguistics ended up turning into discourse analysis. This is the reason why, in the view of many researchers, Text Linguistics has evolved into Discourse Analysis in the $21^{\text {st }}$ century, where it is difficult to deny the great influence that contextual factors exert over the meaning that is finally agreed by the interlocutors in any linguistic exchange.

- There are two main schools of Pragmatics: the Anglo-American and the European Continental. The former can be identified with micro-pragmatics and the latter with macro-pragmatics. If we looked at Pragmatics exclusively through the European Continental school prism, it would be difficult to see any difference between Pragmatics and Discourse Analysis, and in such a case the existence of one of them would make no sense. However, the view I advocate herein sees the two disciplines as related but apart, for it is a fact that the research traditions of Pragmatics and Discourse Analysis have been different in spite of their several points of convergence.

Pragmatic studies are generally oriented towards the discussion of theoretical issues having to do with the underdeterminacy of language, thus dealing with implied, non-literal meanings, or what Grice (1975) called meaning-nn (i.e. non-natural meaning), as opposed to semantic, literal or timeless meaning (i.e. Grice's natural meaning), the latter being the concern of Semantics. And here I refer to Semantics in its narrow sense (i.e. the kind of Semantics that deals with truth-conditional meaning) because in a broader sense, and considering that Pragmatics deals mainly with meaning, it can be said that Pragmatics belongs in the realm of Semantics as well.

- Discourse Analysis, like Pragmatics, is concerned with language in use and in context. Pragmatics is an indispensable source for, but is not the same as Discourse Analysis. Discourse Analysis draws on the concepts and tools of Pragmatics, but the former is a broader, more empirically-oriented discipline than the latter, because it includes many schools and traditions which are not necessarily found within the scope of Pragmatics. Pragmatics, on the other hand, is a more theoretically-oriented discipline, which has traditionally been concerned with topics (such as speech acts, implicatures or reference) which are used by, but are not necessarily central topics within, discourse studies.

(C) Laura Alba-Juez, 2016

\section{REFERENCES}

Alba-Juez, Laura (2001 [1996]). The Functions and Strategies of Ironic Discourse: An Analysis. Madrid: Universidad Complutense de Madrid. Doctoral Thesis. 
Alba-Juez, Laura (2009). Perspectives on Discourse Analysis: Theory and Practice. Newcastle Upon Tyne: Cambridge Scholars Publishing.

Alba-Juez, Laura (2014). Irony as inferred contradiction. In: Vestnik of People's Friendship University of Russia. Linguistics Series, 2014, $\mathrm{n}^{\mathrm{o}}$ 4. 140-153.

Alba-Juez, Laura \& Salvatore Attardo (2014). The evaluative palette of verbal irony. In Geoff Thompson \& Laura Alba-Juez (eds), Evaluation in Context. Amsterdam: John Benjamins. 93-115.

Alba-Juez, Laura \& Mackenzie, J. Lachlan (2016). Pragmatics: Cognition, Context and Culture. Madrid: McGraw Hill.

Ariel, Mira. (2010). Defining pragmatics. Cambridge: Cambridge University Press.

Bourdieu, Pierre (1990). The Logic of Practice. Stanford: Stanford University Press.

Bublitz, Wolfram \& Neal R. Norrick. (2011). The burgeoning field of pragmatics. In Wolfram Bublitz \& Neal R. Norrick (eds.), Foundations of pragmatics, 1-20. Berlin: De Gruyter Mouton.

Brown, G. \& G. Yule (1983). Discourse Analysis. Cambridge: Cambridge University Press.

Candlin, C.N. (1997). General editor's preface. In Gunnarsson, B.-L., Linell, P. and Nordberg, B. (eds.). The Construction of Professional Discourse. London: Longman, ix-xiv.

Chafe, William (1980). The deployment of consciousness in the production of a narrative. In W. Chafe (ed.), The Pear Stories: Cognitive, Cultural and Linguistic Aspects of Narrative Production. Norwood, NJ: Ablex Press, 9-50.

Chafe, William (1987). Cognitive constraints on information flow. In R. Tomlin (ed.), Coherence and Grounding in Discourse. Amsterdam: John Benjamins, 21-51.

Chafe, William (1992). Prosodic and functional units of language. In J. Edwards and M. Lampert (eds.), Talking Data: Transcription and Coding in Discourse Research. Hillsdale, NJ: Lawrence Erlbaum Associates.

Crystal, D. (1997). A Dictionary of Linguistics and Phonetics. Oxford: Blackwell.

Cummings, Louise. (2005). Pragmatics: A multidisciplinary perspective. Edinburgh: Edinburgh University Press.

de Beaugrande, R. (1997). New Foundations for a Science of Text and Discourse: Cognition, Communication, and the Freedom of Access to Knowledge and Society. Vol. LXI in the series Advances in Discourse Processes, R. O. Freedle (ed.). Norwood, NJ: Ablex Publishing.

de Beaugrande, R. \& W. Dressler (1981). Introduction to Text Linguistics. London \& New York: Longman.

Dewaele, Jean Marc (2013). Emotions in Multiple Languages. London: Palgrave Macmillan.

Dooley, Robert A. \& Stephen H. Levinsohn (2000). Analyzing Discourse: A Manual of Basic Concepts. North Dakota: SIL International \& University of North Dakota.

Fairclough, N. (1989). Language and Power. London: Longman.

Fasold, R. (1990). Sociolinguistics of Language. Oxford: Blackwell.

Foolen, Ad (2012). The relevance of emotion for language and linguistics. In Ad Foolen, Ulrike M. Lüdtke, Timothy P. Racine \& Jordan Zlatev (eds.). In Moving Ourselves, Moving Others: Motion and Emotion in Intersubjectivity, Consciousness and Language. Amsterdam \& Philadelphia, PA: John Benjamins. 347-368.

Foolen, Ad (2016). Expressives. In Nick Riemer (ed.), The Routledge Handbook on Semantics. London \& New York: Taylor and Francis, 473-490.

Forceville, Charles \& Billy Clark (2014). Can pictures have explicatures? Linguagem em (Dis)curso 14(3). 451-472. 
Foucault, M. (1972). The Archaeology of Knowledge. London: Tavistock.

Grice, H.P. (1975). Logic and conversation. In P. Cole and J. Morgan (eds.) Syntax and Semantics 3: Speech Acts. New York: Academic Press, 41-58.

Halliday, Michael A.K. (1978). Language as Social Semiotic. London: Edward Arnold.

Huang, Yan (2016). Pragmatics: Language use in context. In Keith Allan (ed.), Routledge handbook of linguistics, 205-220. London \& New York: Routledge.

Hunston, Susan \& Geoff Thompson (eds.) (2000). Evaluation in Text: Authorial Stance and the Construction of Discourse. Oxford: Oxford University Press.

Johnson Laird, P.N. (1983). Mental Models: Towards a Cognitive Science of Language, Interference, and Consciousness. Cambridge, MA: Harvard University Press.

Johnstone, Barbara (2008). Discourse Analysis. Second Edition. Oxford: Blackwell Publishing.

Leech, Geoffrey N. (1983). Principles of pragmatics. London: Longman.

Levinson, Stephen C. (1983). Pragmatics. Cambridge: Cambridge University Press.

Martin, James R. \& Peter R.R. White (2005). The Language of Evaluation: Appraisal in English. New York: Palgrave Macmillan.

Mey, Jacob L. (1993). Pragmatics: An introduction. 2nd edition. Oxford: Blackwell.

Schiffrin, Deborah (1994). Approaches to Discourse. Oxford: Basil Blackwell.

Slembrouck, S. (2006). What is meant by 'discourse analysis'? Department of English, University of Gent. At: http://bank.rug.ac.be/da/da.htm.

Verschueren, Jef. (2009). Introduction: The pragmatic perspective. In Jef Verschueren \& Jan-Ola Östman (eds.), Key notions for pragmatics, 1-27. Amsterdam \& Philadelphia, PA: John Benjamins.

Thompson, Geoff \& Laura Alba-Juez (eds.) (2014). Evaluation in Context. Amsterdam: John Benjamins.

Titscher, S.M., R. Meyer, R. Wodak \& E. Vetter (2000). Methods of Text and Discourse Analysis. London: Sage.

Wetherell, M.; Taylor, S. \& S.J. Yates (2001) (eds.). Discourse Theory and Practice: A Reader. London: Sage Publications.

Yule, George. (1996). Pragmatics. Oxford: Oxford University Press.

\section{Article history:}

Received: 18 August 2016

Revised: 11 September 2016

Accepted: 20 September 2016

\section{For citation:}

Alba-Juez, L. (2016). Discourse Analysis and Pragmatics: Their Scope and Relation. Russian Journal of Linguistics, 20 (4), 43-55.

\section{Bio Note:}

Laura Alba-Juez, DSc, Professor, Vice-Dean of Faculty of Philology at National Distance Education University (Madrid, Spain). Research interests: Discourse Analysis, Pragmatics, Intercultural Communication, General Linguistics. Contact information: https://portal.uned.es; e-mail: lalba@flog.uned.es 
УДК: 811. 111. 42

DOI: $10.22363 / 2312-9182-2016-20-4-43-55$

\title{
ДИСКУРС-АНАЛИЗ И ПРАГМАТИКА: ОБЛАСТЬ ИССЛЕДОВАНИЯ И ВЗАИМОСВЯЗЬ
}

\author{
Лаура Альба-Хуэс \\ Национальный университет дистанционного образования \\ 28040, Мадрид, Испания, 7 Passeo Senda del Rey
}

\begin{abstract}
В данной статье автор детально описывает такие научные направления, как дискурс-анализ и прагматика, пытаясь решить сложную задачу - определить область исследования, а также выявить их сходства и различия, с тем чтобы дать общее представление об уровне развития обеих дисцсиплин в 21 веке. Ввиду того, что изучение трудов исследователей в любой научной отрасли является очень важным, в особенности, в том случае, когда научные направления трудно разграничить, автор также рассматривает конкретные работы ученых в сфере прагматики и дискурс-анализа. В статье описаны различные подходы к определению концептов «текст» и «дискурс» через анализ исследований в области лингвистики текста и дискурс-анализа. Кроме того, автор представляет ретроспективу развития данных понятий с момента их возникновения и до настоящего времени. Также описываются основные школы прагматики - Англо-американская и Континентальноевропейская школы (Huang 2016) - и сопоставлются их идеи в области дискурс-анализа. В понимании автора прагматика отличается от дискурс-анализа, но в то же время является для него необходимым источником: не имея достаточных знаний прагматики и ее взаимосвязи с дискурсанализом, невозможно анализировать дискурс (Alba-Juez, 2009:46). В статье также рассматриваются некоторые значимые для исследования понятия и вопросы, например контекст, сознание и культура, а также обозначена необходимость развития прагматической компетенции.
\end{abstract}

Ключевые слова: прагматика, дискурс, дискурс-анализ, контекст, сознание, культура

\section{История статьи:}

Дата поступления в редакцию: 18 августа 2016

Дата принятия к печати: 20 сентября 2016

\section{Для цитирования:}

Alba-Juez L. Discourse Analysis and Pragmatics: Their Scope and Relation // Вестник Pоссийского университета дружбы народов. Серия: Лингвистика. 2016. Т. 20. № 4. С. 43-55.

\section{Сведения об авторе:}

Лаура Альба-Хуэс, доктор, профессор, заместитель декана филологического факультета, координатор докторских программ по филологии в Национальном университете дистанционного образования (Мадрид, Испания). Сфера научных интересов: анализ дискурса, прагматика, межкультурная коммуникация, общее языкознание. Контактная информация: https://portal.uned.es; e-mail: lalba@flog.uned.es 